\title{
PEMBERDAYAAN INDUSTRI KOPRA PUTIH DI NUSA TENGGARA TIMUR YANG BERKUALITAS DAN BERDAYA SAING TINGGI
}

\author{
Adrianus Amheka ${ }^{1)}$, Sulche I. Nafi ${ }^{2}$ ), Herianus J. D Lalel ${ }^{3)}$ \\ ${ }^{1)}$ Jurusan Teknik Mesin, Politeknik Negeri Kupang \\ ${ }^{2}$ Jurusan Akuntansi, Politeknik Negeri Kupang \\ ${ }^{3)}$ Fakultas Pertanian, Universitas Nusa Cendana \\ email: adrianus.amheka@gmail.com
}

\begin{abstract}
Abstrak
Beberapa kendala industri kopra di Provinsi NTT tidak berkembang baik oleh karena menurunnya produktivitas dengan menerapkan sistim konvensional selain kurangnya kapasitas masyarakat dalam memahami kondisi optimal produk guna menjaga kualitas dan daya saing produk. Untuk menjaga peningkatan dan keberlanjutan produk tersebut sekaligus menjawab permasalahan masyarakat usaha kopra perlu adanya dukungan majamen yang kuat selain upaya menumbuh kembangkan semangat inovasi dan keunikan produk berdaya saing tinggi. Obyek pengabdian dilakukan pada Industri kopra "Bangun Mandiri" yang berlokasi di Kota Kupang, Provinsi NTT guna berdampak pada intensitas produk serta kapasitas pekerja yang jauh lebih efisien. Adapun tujuan program untuk memperluasan pemasaran antar pulau guna meningkatkan kualitas dan daya saing produk sekaligus penopang kesejahteraan masyarakat. Solusi penyediaan mesin dan peralatan pendukung serta rehabilitasi rumah produksi dan manajemen menjadi fokus aktivitas program. Adapun hasil yang dicapai sesuai tujuan dan target dalam bentuk realisasi pemecahan masalah antara lain peningkatan kualitas dan kuantitas produk kopra putih; peningkatan investasi fasilitas pendukung pemasaran; peningkatan omzet penjualan mencapai 30\% pertahun serta stimulasi jiwa inovasi mitra industri yang mengashilkan diversifikasi produk olahan kopra yang unik, berdaya saing tinggi yang berdampak pada perluasan wilayah pemasaran antar pulau secara professional.
\end{abstract}

Kata Kunci : Industri kopra, mesin pengering, produktivitas.

\section{PENDAHULUAN}

Umumnya Industri kopra di Provinsi NTT terkendala dalam hal produktivitas produk, dimana penyebab antara lain oleh karena industri kopra di Pulau Timor memanen kopra secara konvensional dan tradisional yang masih terkandung parasit dan sejenisnya selain kurangnya kapasitas masyarakat dalam memahami kondisi optimal dalam hal menjaga kualitas kopra yang besar kemungkinan karena tidak adanya diversifikasi mekanisasi. Untuk menjaga peningkatan dan keberlanjutan produk kopra tersebut sekaligus menjawab permasalahan masyarakat usaha kopra di NTT perlu adanya dukungan majamen yang kuat melalui perbaikan fisik rumah produksi dan penyediaan fasilitas pendukung, desain termaksud perbaikan mesin penggering kopra yang telah ada sebelumnya dengan mempertimbangkan faktor efektivitas dengan target kopra berkadar air 5\% kebawah. Selain itu upaya menumbuh kembangkan semangat inovasi dan keunikan produk dan hasil produk yang berdaya saing tinggi. Obyek pengabdian dilakukan pada
Industri kopra"Bangun Mandiri” yang berlokasi di Kota Kupang, NTT guna berdampak pada intensitas produk yang lebih tinggi serta aktivitas pengembangan kapasitas pekerja lebih efisien dan optimal. Berikut pola hubungan antara perguruan tinggi (Politeknik Negeri Kupang) dan Industri mitra kopra terukur baik seperti kerangka kerja dibawah:

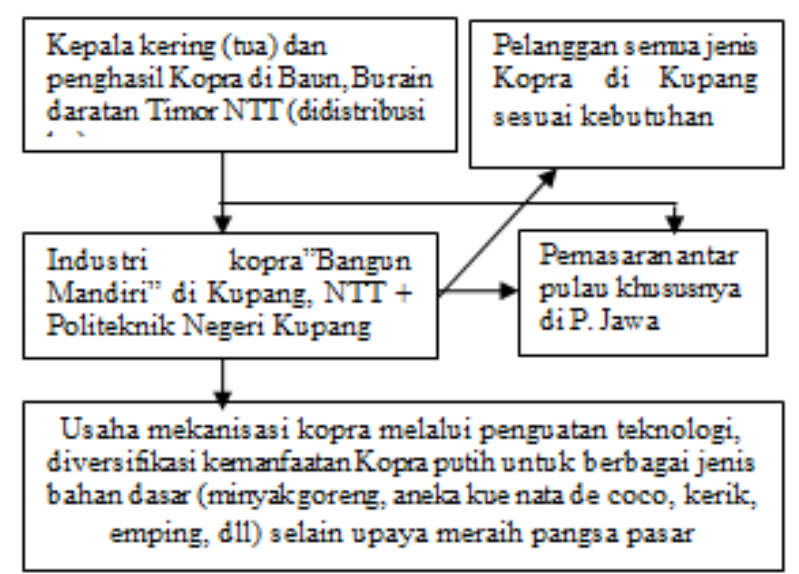

Terkait dengan hal tersebut diatas maka program ini difokuskan pada: (1). Perbaikan rumah 
produksi dan fasilitas pendukung manajemen; (2) Penyempurnaan bagian-bagian penting pada mesin pengering kopra sistim tungku hole-vertical dalam rangka peningkatan jualitas dan kuantitas produk; (3). Menumbuh kembangkan jiwa inovasi melalui penyediaan mesin dan peralatan penunjang hasil produk olahan kopra untuk produk yang unik dan berdaya saing tinggi di tingkat lokal dan nasional serta berorientasi ekspor; (3). Kontribusi Disperindag Kota Kupang melalui kegiatan pengembangan kapasitas industri mitra kopra serta intervensi kebijakan pemberdaayan industri kopra lokal berorientasi ekspor. Adapun tujuan terukur program pengabdian ini untuk mencapai kapasitas produksi yang stabil sesuai permintaan pasar melalui kestabilan nilai tambah produk guna meningkatkan dan mengembangkan sumber daya peralatan berupa penguatan teknologi produksi dan manajemen kearah multi efek penelitian dasar dan terapan dimasa mendatang dari aspek memaksimalkan hasil produk dan produk sampingan untuk menjaga kelestarian lingkungan dan keberlanjutan produktivitas dimasa mendatang.

\section{METODE KEGIATAN}

Dengan menerapkan metode tindakan, berikut beberapa metode yang borientasi pada penerapan teknologi yang akan dilakukan antara lain:

1. Menghasilkan produk kopra khas NTT berkualitas baik secara berkelanjutan melalui sentuhan dukungan kepada manajemen mitra industri melalui perbaikan fisik rumah produksi serta menyiapkan fasilitas pendukung Komputer, serta alat-alat pendukung produksi dalam rangka pencapaian kinerja professional.

2. Penerapan dan pemantapan manajemen produksi dan keuangan dilakukan bertahap dengan menerapkan prinsip-prinsip akuntansi sederhana dan benar yang ditekanan pada budaya keharusan mendokumentasikan setiap transasksi yang dilakukan berupa pengarsipan catatancatatan, nota-nota, arsip jenis dan jumlah produk, surat jalan, catatan penting lainnya yang diharapkan dapat dijadikan dasar dalam menyusun neraca keuangan mengacu pada omzet dan kondisi investasi serta keadaan indutri Mitra.
3. Penyempurnaan dan perbaikan desain Mesin oven pengering kopra multi fungsi sistim holetungku vertikal pada bagian pintu, buangan cerobong dan landasan tungku untuk menghasilkan kopra putih berkadar air rendah

4. Penyediaan mesin pembuat emping kopra sebagai upaya potensi inovasi bernilai tambah pada produk.

Dalam implenetasi metode tersebut diharapkan target peningkatan omzet pertahun meningkat dan perlasan wiayah epmasaran dapat terjangkau luas.

\section{HASIL DAN PEMBAHASAN}

Kegiatan pengabdian ini yang borientasi pada IPTEKS dimana pengoperasian alat serta perlindungan hasil produk menjadi tolak ukur pelaksaan guna pencapaian target sesuai metode pelaksaan serta terwujud pemberdayaaan masyarakat produktif. Adapun penekanan terukur diarahkan pada aspek penguatan manajemen mitra industri dengan melakukan perbaikan fisik rumah produksi serta penyediaan fasilitas standar seperti komputer, mesin printer dan aspek administrasi lainnya. Selain itu, dukungan aspek inovasi hasil produk berupa penyediaan mesin pembuat emping kopra sebagai langkah strategis upaya dukungan inovasi emping berbahan kopra yang akan dipadukan dengan emping jagung dan emping berbahan dasar lainnya dalam satu kemasan. Lebih lanjut, penyempurnaan termaksud perbaikan pada beberapa bagian penting oven pengering dalam rangka lebih mengoptimalkan proses produksi kopra selain tetap kosistensi dukungan peralatan pendukung produksi seperti penyediaan Arco pengangkut, karung berkualitas dan berlabel sebagai wadah penyimpanan kopra. Adapun tabel hasil berupa luaran program pengabdian sebagai berikut: 


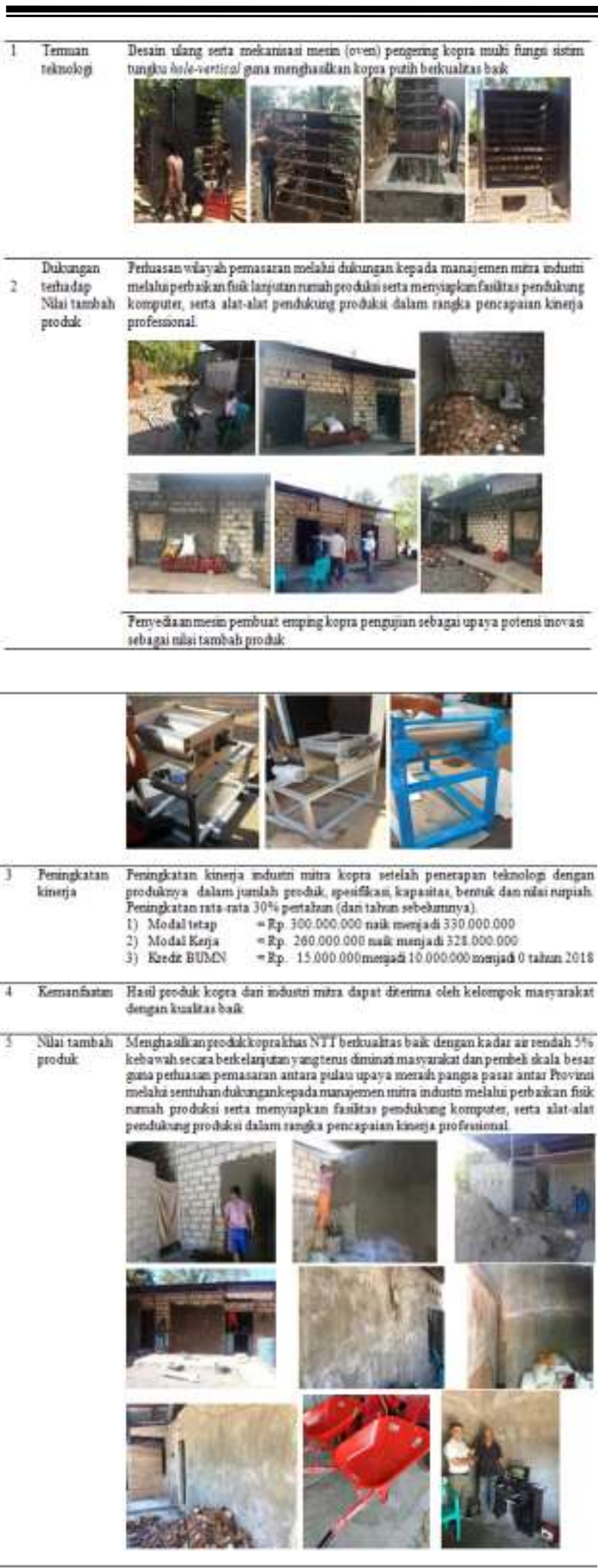

Adapun bentuk realisasi pemecahan masalah seperti peningkatan kualitas dan kuantitas produk kopra putih melalui penyempurnaan dan perbaikan mesin oven pengering kopra multi fungsi sistim tungku hole-vertical; perbaikan fisik rumah produksi dan manajemen mitra industri sebagai peningkatan investasi fasilitas pendukung pemasaran; peningkatan omzet penjualan tahunan sebesar 30\%, stimulasi jiwa inovasi mitra industri melalui sentuhan penyediaan peralatan emping dari bahan kopra sebagai keunikan tersendiri dan berdaya saing tinggi tingkat regional dan nasional; dan perluasan wilayah pemasaran melalui kemitraan kerjasama pemasaran antar pulau secara professional melalui intevensi Pemda. Adapun indikator capaian nilai tambah produk seperti tergambar pada framework berikut:

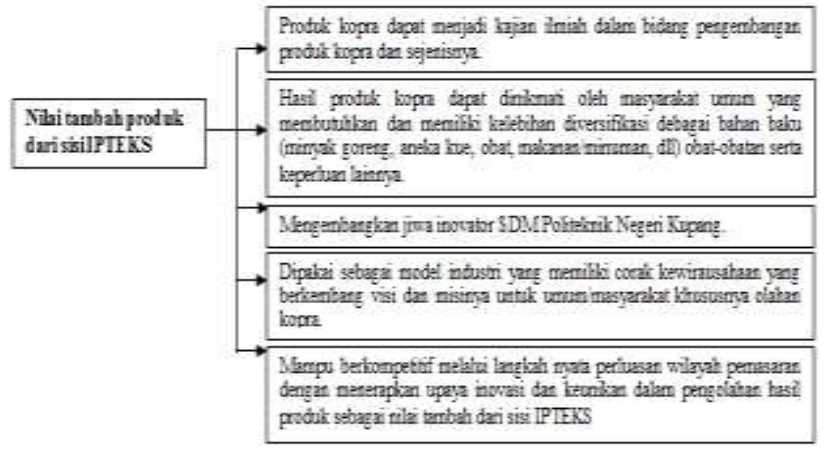

\section{KESIMPULAN}

Kesimpulan dari program pegabdian ini antara lain: Meningkatan kualitas dan kuantitas produk Kopra putih serta peningkatan daya saing produk melalui dukungan perbaikan rumah produksi beserta fasilitas manajemen guna kehandalan produk; menumbuhkembangkan jiwa inovasi melalui penyediaan mesin dan peralatan pendukung produksi yang memadai serta membuka akses pemasaran melalui intervensi upaya kebijakan Pemda dalam menjaga kestabilan pemasaran produk kopra dan hasil olahan kopra NTT yang unik, berkualitas dan digemari pasar secara berkelanjutan; Penyempurnaan mesin pengering kopra multi fungsi sistim tungku hole-vertical dalam rangka peningkatan kualitas produk yang terjamin berkelanjuta sekaligus sebagai peningkatan investasi penambahan peralatan dan mesin oven; Peningkatan omzet penjualan sebesar 30\%, Penelitian skala Lab untuk kemungkinan mengkonsumsi batok kelapa kering yang telah diovenkan untuk bahan tambahan makanan/minuman beraroma kopra; dan Perluasan 
wilayah pemasaran melalui kemitraan kerjasama pemasaran antar pulau skala nasional dan internasional.

\section{REFERENSI}

Amheka, A. (2016) Mekanisasi dan Diversifikasi Produk Kopra NTT Untuk Meningkatkan Pangsa Pasar Antar Pulau, Jurnal Aplikasi Ipteks NGAYAH Vol.7 (2), ISSN: 2087-118X. p.117-127 Unmas.

Asba, R. (2007) Kopra Makassar Perebutan Pusat dan Daerah: Kajian Sejarah Ekonomi Politik Regional di Indonesia Kajian Sejarah Ekonomi
Politik Regional di Indonesia. Yayasan Obor Indonesia 2007

Amheka, A. (2015) Identifikasi Rancangan Teknologi dan Pengembangan Produk Kopra NTT. Perpustakaan Politeknik Negeri Kupang.

Amheka, A. (2016) Kopra dan Pemanfaatan Pada Industri Pangan Nasional. Perpustakaan Politeknik Negeri Kupang.

Amheka, A. (2018) Pemberdayaan Industri Kopra Putih NTT yang berkualitas dan Berdaya Saing Tinggi, Laporan Program Pengabdian kepada Masyarakat. Perpustakaan Politeknik Negeri Kupang. 